\title{
Mild spherocytosis and altered red cell ion transport in protein 4.2-null mice
}

\author{
Luanne L. Peters, ${ }^{1}$ Hitesh K. Jindel, ${ }^{2}$ Babette Gwynn, ${ }^{1}$ Cathy Korsgren,, 3 \\ Kathryn M. John, ${ }^{3}$ Samuel E. Lux, ${ }^{3}$ Narla Mohandas, ${ }^{4}$ Carl M. Cohen, ${ }^{2}$ \\ Michael R. Cho, ${ }^{5}$ David E. Golan, ${ }^{5}$ and Carlo Brugnara ${ }^{6}$
}

${ }^{1}$ The Jackson Laboratory, Bar Harbor, Maine 04609, USA

${ }^{2}$ Department of Biomedical Research, St. Elizabeth's Medical Center, Boston, Massachusetts 02135, USA

${ }^{3}$ Division of Hematology/Oncology, Department of Medicine, Children's Hospital and Department of Pediatric Oncology,

Dana Farber Cancer Institute, Boston, Massachusetts 02115, USA

${ }^{4}$ Lawrence Berkeley National Laboratory, University of California-Berkeley, Berkeley, California 94720, USA

${ }^{5}$ Departments of Medicine and of Biological Chemistry and Molecular Pharmacology, Harvard Medical School and

Hematology Division, Brigham and Women's Hospital, Boston, Massachusetts 02115, USA

${ }^{6}$ Department of Laboratory Medicine, Children's Hospital, Boston, Massachusetts 02115, USA

Address correspondence to: Luanne L. Peters, The Jackson Laboratory, 600 Main Street, Bar Harbor, Maine 04609, USA.

Phone: (207) 288-6391; Fax: (207) 288-6073; E-mail: luanne@aretha.jax.org.

Received for publication November 10, 1998, and accepted in revised form April 14, 1999.

Protein 4.2 is a major component of the red blood cell (RBC) membrane skeleton. We used targeted mutagenesis in embryonic stem (ES) cells to elucidate protein 4.2 functions in vivo. Protein 4.2 -null $\left(4.2^{-/}\right)$mice have mild hereditary spherocytosis (HS). Scanning electron microscopy and ektacytometry confirm loss of membrane surface in $4.2^{-/-} \mathrm{RBCs}$. The membrane skeleton architecture is intact, and the spectrin and ankyrin content of $4.2^{-/-}$RBCs are normal. Band 3 and band 3 -mediated anion transport are decreased. Protein $4.2^{-/-} \mathrm{RBCs}$ show altered cation content (increased $\mathrm{K}^{+} /$decreased $\mathrm{Na}^{+}$) resulting in dehydration. The passive $\mathrm{Na}^{+}$permeability and the activities of the $\mathrm{Na}-\mathrm{K}-2 \mathrm{Cl}$ and $\mathrm{K}-\mathrm{Cl}$ cotransporters, the $\mathrm{Na} / \mathrm{H}$ exchanger, and the Gardos channel in 4.2/- RBCs are significantly increased. Protein 4.2-/- RBCs demonstrate an abnormal regulation of cation transport by cell volume. Cell shrinkage induces a greater activation of $\mathrm{Na} / \mathrm{H}$ exchange and $\mathrm{Na}-\mathrm{K}-2 \mathrm{Cl}$ cotransport in $4.2^{-/-} \mathrm{RBC}$ compared with controls. The increased passive $\mathrm{Na}^{+}$permeability of $4.2^{-/-} \mathrm{RBCs}$ is also dependent on cell shrinkage. We conclude that protein 4.2 is important in the maintenance of normal surface area in RBCs and for normal RBC cation transport.

J. Clin. Invest. 103:1527-1537 (1999).

\section{Introduction}

Protein 4.2 is a $72-\mathrm{kDa}$ component of the red blood cell (RBC) membrane skeleton (200,000 copies per RBC) (1). An intact membrane skeleton attached to the lipid bilayer by vertical interactions between spectrin, ankyrin, protein 4.2, and band 3 (anion exchanger 1 [AE1]) is required for normal $\mathrm{RBC}$ membrane integrity. Defects in all of these components have been identified in hereditary spherocytosis (HS) (2). In humans, protein 4.2 defects are most common in people of Japanese descent and give rise to pleiotropic $\mathrm{RBC}$ morphological changes and hemolytic anemias of varying severity (3).

In RBCs, protein 4.2 binds to the cytoplasmic domain of band 3 (4). In solution, protein 4.2 binds directly to spectrin, ankyrin, and protein 4.1 , and promotes binding of spectrin to ankyrin-depleted inside-out vesicles (4, $5)$. The significance of these interactions in vivo is unknown. However, mice totally deficient in band 3 are also completely protein 4.2 deficient, suggesting that band 3 is critical for stable incorporation of protein 4.2 into the membrane skeleton (6).

Hereditary spherocytes are characterized by increased $\mathrm{Na}^{+}$and decreased $\mathrm{K}^{+}$content compared with normal RBCs (2). Studies in mice and humans suggest that the cation alterations are the result of increased passive RBC membrane permeability and that the increased passive flux reflects the overall loss of membrane skeleton integrity, not the specific protein defect $(7,8)$. Protein 4.2 has been proposed to negatively regulate band 3-mediated $\mathrm{RBC}$ anion transport (9), but its role in regulating RBC cation transport and intracellular cation content is unknown.

We targeted the erythrocyte protein 4.2 gene (Epb4.2) in embryonic stem (ES) cells to create a null mutation (4.2-/-) in mice. Deficiency of protein 4.2 in mice results in mild HS. Normal amounts of spectrin and ankyrin are assembled onto the membrane, and the membrane skeleton architecture is intact. The band 3 content of the membrane is decreased. Contrary to previous reports, band 3 -mediated anion transport in not increased in $4.2^{-/-}$ RBCs, but is decreased. Protein 4.2-deficient RBCs show significant changes in RBC cation transporter activities. These changes are in marked contrast to those obtained in spectrin- and ankyrin-deficient mouse and human red cells $(7,8)$, suggesting that specific membrane skeleton defects differentially influence cation transporter activities. Our results show that protein 4.2 is important in the maintenance of normal surface area in RBCs and is required for normal $\mathrm{RBC}$ cation transport. 
a
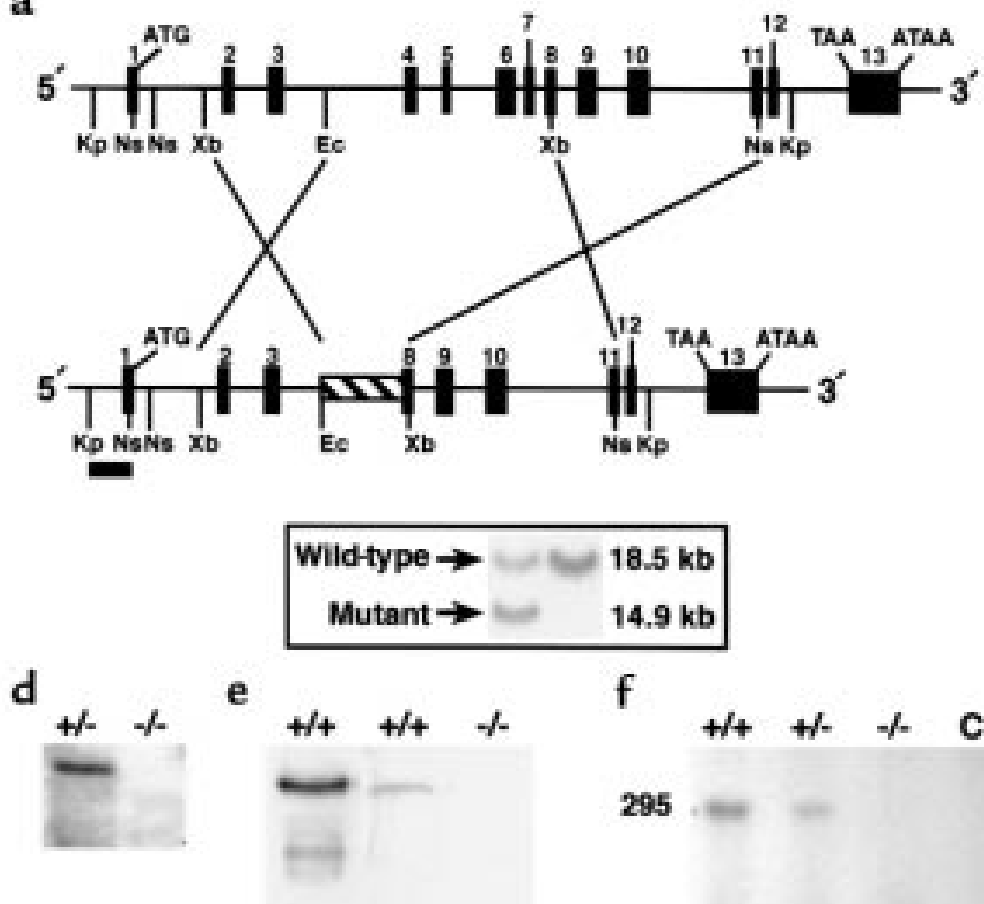

RBC PLT PLT b

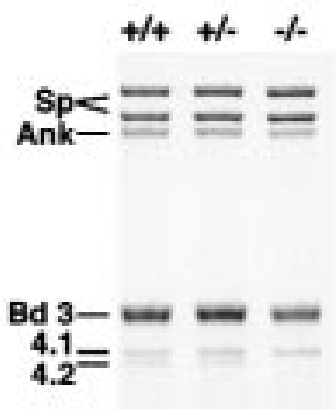

c
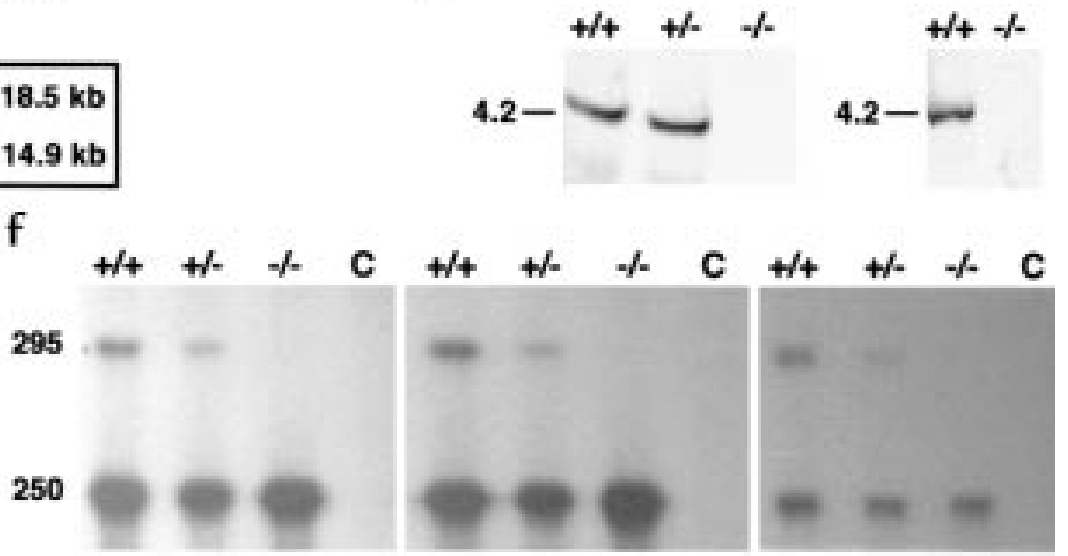

Figure 1

Epb4.2 gene targeting results in a null mutation. (a) Restriction map of the Epb4.2 locus with the targeted allele shown below. Numbered boxes represent exons. Upon homologous recombination in ES cells, a neomycin-resistant cassette (hatched box) replaced a segment of the gene extending from intron 3 to exon 8. A 667-bp 5'-flanking Kpnl-Nsil fragment (filled bar) was used as the hybridization probe to distinguish alleles by Southern blot analysis. Kp, Kpnl. Ns, Nsil. Xb, Xbal. Ec, EcoRI. Inset: Southern blot analysis. Homologous recombination occurred in 6 of 114 clones, as indicated by the presence of both the wild-type (18.5 kb) and targeted (14.9 kb) alleles in Kpnl-digested DNA. (b) SDS-PAGE analysis (Fairbanks' method) of RBC membranes ( $5 \mu \mathrm{g}$ protein per lane). Protein 4.2 is undetectable and band 3 decreased in $4.2^{-/-}$RBCs. (c) Immunoblot analysis of RBC membrane ghosts (left; $5 \mu \mathrm{g}$ protein per lane) and whole-cell lysates (right; $2.5 \mu \mathrm{L}$ packed cells per lane). The blots were probed with a polyclonal antibody raised against purified human erythrocyte 4.2 (19). (d) Northern blot analysis of reticulocyte RNA from newborn mice ( $5 \mu \mathrm{g}$ per lane). The filters were probed with a 2.4-kb mouse protein $4.2 \mathrm{cDNA}(1)$. (e) Immunoblot of whole-platelet lysates probed with 4.2 antisera, as in c. Lane 1, $1.0 \mu \mathrm{g}$ normal RBC membranes; lane 2, $3.0 \mu \mathrm{g}$ normal platelet lysate; lane 3, $6.0 \mu \mathrm{g} 4.2^{-/-}$platelet lysate. (f) RNase protection assay of kidney mRNA. Perfused kidney mRNA (10 $\mu$ g per lane) was hybridized with a 295 -bp ${ }^{32}$ P-labeled riboprobe corresponding to nucleotides 726-1019 (1) within the targeted region of protein 4.2 cDNA. In the left, middle, and right panels, RNase dilutions of 1:200, 1:100, and 1:50 were used, respectively. C is the RNA-free control lane. Sp, spectrin. Ank, ankyrin. bd 3, band 3. 4.1, protein 4.1. 4.2, protein 4.2. RBC, red blood cell ghost membranes. PLT, whole-platelet lysates.

\section{Methods}

Gene targeting. Mouse protein 4.2 genomic clones were isolated from a $129 / \mathrm{Sv} \lambda$ FixII library (Stratagene, La Jolla, California, USA). A 3.1-kb XbaI-EcoRI fragment extending from intron 1 to intron 3 was subcloned into the EcoRI-XbaI sites of the pPNT (10) vector, and a 5.1-kb XbaI-NsiI fragment extending from exon 8 to exon 11 was subcloned into the XhoI site. Transfected E14 ES cells (11) were cultured and selected in G418 and ganciclovir. Genomic DNA was digested with $K p n \mathrm{I}$ and analyzed by Southern blotting using a flanking 667-bp KpnI-Nsi fragment as the hybridization probe (Figure 1a). Blastocyst injection and embryo transfer were performed using standard techniques (12). Male chimeras, identified by coat color, were mated to C57BL/6J females to generate heterozygotes.

Genotyping of progeny. Genomic tail DNA (Gentra Systems, Minneapolis, Minnesota, USA) was used to genotype progeny by PCR. For the detection of the wild-type allele, the protein 4.2-specific oligonucleotides 5'-CTGGAGCATGCTGGTTGAAC-3' and 5'-GAGGGTTGAGAGAAGCAGCA-3' were used as forward and reverse primers, respectively, and amplified a 488-bp fragment (1). The protein 4.2-specific primer 5'-AGGACGAGAACTAGGAAGAG-3' and neo ${ }^{\mathrm{R}}$-specific primer 5'-TCTATCGCCTTCTTGACGAG-3' amplified a 699-bp fragment corresponding to the mutant allele.

Detection of Epb4.2 gene products. Total RNA was isolated as described (13). Northern blotting was performed by standard techniques using a 2.4-kb mouse protein $4.2 \mathrm{cDNA}$ as probe (1). For RNase protection assays, $10 \mu \mathrm{g}$ of perfused kidney mRNA was hybridized with a ${ }^{32} \mathrm{P}$-labeled riboprobe corresponding to a portion of the targeted protein $4.2 \mathrm{cDNA}$ (nucleotides 726-1019) (1). In vitro transcription and RNase protection assays were performed according to the manufacturer's specifications (Ambion Inc., Austin, Texas, USA). Hemoglobindepleted RBC ghosts and whole-cell lysates were prepared as described previously (6). SDS-PAGE was performed using the method of Steck (14) or Laemmli (15). Coomassie blue-stained gels were scanned using a computing densitometer (Molecular Dynamics, Sunnyvale, California, USA). At least 3 lanes of ghosts from each mouse were scanned, and the results were averaged to minimize variations in gel loading, staining, etc. 
Immunoblots of RBC proteins were performed using rabbit polyclonal antibodies to spectrin (16), ankyrin (17), protein 4.1 (18), and protein 4.2 (19), or peptide antibodies recognizing the COOH-terminus of mouse AE1 (20). The p55 antiserum was kindly provided by A. Chishti (St. Elizabeth's Medical Center, Boston, Massachusetts, USA) (21). Anti-glycophorin C (GPC) was the kind gift of M. Reid (New York Blood Center, New York, New York, USA). Bound antibody was visualized using alkaline phosphatase detection (Bio-Rad Laboratories Inc., Hercules, California, USA) or enhanced chemiluminescence reagents from Amersham Life Sciences Inc. (Arlington Heights, Illinois, USA). Whole-platelet lysates were prepared and bleeding times determined as described previously $(22,23)$. Protein concentrations were determined using Bradford's method (Bio-Rad Laboratories Inc.).

Hematological analysis. Blood counts were determined using an automated hematology analyzer (Technicon H3; Bayer Diagnostics, Tarrytown, New York, USA). Whole blood was collected in EDTA-coated microtiter tubes (Becton Dickinson, Rutherford, New Jersey, USA). Smears were stained with Wright-Giemsa (Sigma Chemical Co., St. Louis, Missouri, USA). Reticulocytes were enumerated after staining with new methylene blue.

Histology/electron microscopy. Mice were anesthetized and perfused with $20 \mathrm{~mL}$ Bouin's fixative. Tissues were placed in fresh fixative overnight and processed to paraffin. Sections $(5 \mu \mathrm{m})$ were stained with hematoxylin and eosin, cresyl violet, or Luxol fast blue for routine histological examination, and with Prussian blue for detection of iron. RBCs were prepared for electron microscopic visualization of double-layered, negatively stained membrane skeletons and intramembranous particles (IMPs) as described previously (24).

Osmotic gradient ektacytometry. Fresh RBCs were mixed continuously with a $4 \%$ polyvinylpyrrolidone solution of gradually increasing osmolality (60-600 mOsm), and the deformability index (DI) was recorded as a function of osmolality at a constant applied shear stress of 170 dynes $/ \mathrm{cm}^{2}$ using an ektacytometer (Bayer Diagnostics) (25).

Lateral mobility of band 3. Band 3 lateral mobility was measured as described (26). Band 3 was specifically labeled by incubating intact RBCs with eosin-5-maleimide (Molecular Probes, Eugene, Oregon, USA). Fluorescence photobleaching recovery was used to measure the lateral mobility of eosin-labeled band 3 in membranes of intact RBCs.

Transport studies. Measurement of sulfate transport in RBCs was performed as described previously (27). Maximal Na-K pump, $\mathrm{Na}-\mathrm{K}-2 \mathrm{Cl}$ cotransporter and $\mathrm{Na} / \mathrm{H}$ exchanger activities, and the passive $\mathrm{Na}^{+}$and $\mathrm{K}^{+}$permeabilities were measured in cells equilibrated to $50 \mathrm{mM} \mathrm{Na}^{+}$and $50 \mathrm{mM} \mathrm{K}^{+}$using nystatin in a solution containing $77 \mathrm{mM} \mathrm{NaCl}, 77 \mathrm{mM} \mathrm{KCl}$, and $55 \mathrm{mM}$ sucrose. This treatment yielded mean corpuscular hemoglobin concentration (MCHC) values that were similar to those of fresh cells (Table 1 ) for each of the 3 genotypes $\left(4.2^{-/-}, 34.9 \pm 2.6\right.$ $\mathrm{g} / \mathrm{dL}[n=8] ; 4.2^{+/+}$and $\left.4.2^{+/-}, 31.5 \pm 1.7 \mathrm{~g} / \mathrm{dL}[n=6]\right)$. The Na-K pump activity was measured as the ouabain-sensitive (1 mM) $\mathrm{Na}^{+}$efflux into media containing $10 \mathrm{mM} \mathrm{K}^{+}$. The $\mathrm{Na}-\mathrm{K}-2 \mathrm{Cl}$ cotransporter activities were measured as the bumetanide-sen- sitive $(10 \mu \mathrm{M}) \mathrm{Na}^{+}$and $\mathrm{K}^{+}$efflux into media containing $165 \mathrm{mM}$ isotonic choline chloride, $1 \mathrm{mM} \mathrm{MgCl}$, and $1 \mathrm{mM}$ ouabain. $\mathrm{Na} / \mathrm{H}$ exchanger activities were determined in cells equilibrated to $50 \mathrm{mM} \mathrm{Na}^{+}$and $\mathrm{K}^{+}$as the $H$-methyl amiloride-sensitive (10 $\mu \mathrm{M} H$-methyl amiloride [HMA]) $\mathrm{Na}^{+}$efflux into isotonic choline chloride media containing $1 \mathrm{mM}$ ouabain and $10 \mu \mathrm{M}$ bumetanide. $\mathrm{K}-\mathrm{Cl}$ cotransporter activities were determined in cells exposed to hypotonic swelling as the $\mathrm{Cl}$-dependent $\mathrm{K}^{+}$ efflux. This flux was calculated by subtracting from the $\mathrm{K}^{+}$ efflux into hypotonic $\mathrm{NaCl}$ medium (255-265 mOsml; 115 $\mathrm{mM} \mathrm{NaCl}, 1 \mathrm{mM}$ ouabain, $10 \mu \mathrm{M}$ bumetanide) the $\mathrm{K}^{+}$efflux in hypotonic $\mathrm{Na}$ sulfamate medium (115 $\mathrm{mM}$ Na sulfamate, 1 $\mathrm{mM}$ ouabain, $10 \mu \mathrm{M}$ bumetanide). Gardos channel activities were determined as ${ }^{86} \mathrm{Rb}$ influx into cells incubated in isotonic $\mathrm{NaCl}$ in the presence of the calcium ionophore A23187. Freshly washed RBCs were suspended to a $2 \%$ hematocrit in normal influx media containing $165 \mathrm{mM} \mathrm{NaCl}, 2 \mathrm{mM} \mathrm{KCl}, 0.15 \mathrm{mM}$ $\mathrm{MgCl}_{2}, 1 \mathrm{mM}$ ouabain, $10 \mu \mathrm{M}$ bumetanide, $10 \mathrm{mM}$ Tris-Mops ( $\mathrm{pH}$ 7.4), and $10 \mathrm{mCi}{ }^{86} \mathrm{Rb}$. Free ionic calcium was buffered between 0 and $5 \mu \mathrm{M}$ with $1 \mathrm{mM}$ EGTA or citrate buffer as described previously (28). At time 0,5 mM ionophore A23187 was added to the suspension. Aliquots were removed at $0.33,2$, and 5 minutes and immediately spun through $0.8 \mathrm{~mL}$ of cold medium containing $5 \mathrm{mM}$ EGTA buffer and an underlying cushion of $n$-butyl phthalate. Supernatants were aspirated and the tip containing the cell pellet was cut off. The red cell-associated radioactivity was counted in a gamma counter (model 41600 HE; ICN Biomedicals Inc., Costa Mesa, California, USA).

Volume dependence of $\mathrm{Na}-\mathrm{K}-2 \mathrm{Cl}$ cotransport, $\mathrm{Na} / \mathrm{H}$ exchange, and $\mathrm{Na}^{+}$leakage was studied in cells equilibrated with nystatin to contain equal amounts of $\mathrm{Na}^{+}$and $\mathrm{K}^{+}$. The sucrose in the nystatin loading solution was $45 \mathrm{mM}$ for $4.2^{+/+}$ and $4.2^{+/-}$RBCs and $40 \mathrm{mM}$ for $4.2^{-/-}$RBCs. These sucrose concentrations yielded slightly swollen cells with a final cellular hemoglobin concentration that was similar in the 3 cell types $\left(4.2^{+/+}, 27.0 \pm 0.1 \mathrm{~g} / \mathrm{dL} ; 4.2^{+/-}, 27.5 \pm 0.3 \mathrm{~g} / \mathrm{dL} ; 4.2^{-/-}, 27.7 \pm 0.8\right.$ $\mathrm{g} / \mathrm{dL}[n=3])$. The osmolarity in the flux medium was increased from 260 to $540 \mathrm{mOsm}$ by adding choline chloride.

Other studies. Erythrocytes were metabolically labeled as described (29). Phosphorylated membrane proteins were resolved by SDS-PAGE (15). Gels were dried and autoradiographed using Kodak XAR film. Erythrocyte cytosolic preparations were hemoglobin depleted and immunoblotted using protein kinase $\mathrm{C}$ (PKC) isozyme-specific antibodies (Santa Cruz Biotechnology Inc., Santa Cruz, California, USA) as described $(30,31)$.

PKC assays of erythrocyte cytosol were performed as described (29). The cAMP-dependent kinase (PKA) assay of erythrocyte cytosol was performed according to Danilov et al. (30), and PKA activity was reported as the difference in kinase activity between the samples with and without cAMP. Total cytosolic casein kinase (CK) activity was assayed as described (31). Heparin-inhibitable CK activity, which reflects only casein kinase type II (CKII) activity, was measured in the presence of 2 $\mu \mathrm{g} / \mathrm{mL}$ heparin and was expressed as the difference in the amount of ${ }^{32} \mathrm{P}$ incorporated in the absence and presence of heparin. CKI-7-inhibitable activity, which reflects only casein kinase type I (CKI) activity, was measured as the difference

Table 1

Hematological parameters in adult mice

\begin{tabular}{lcccccccc}
\hline $\begin{array}{l}\text { Genotype } \\
(n)\end{array}$ & $\begin{array}{c}\mathrm{RBC} \\
\left(\times 10^{12} / \mathrm{L}\right)\end{array}$ & $\begin{array}{c}\mathrm{HCT} \\
(\%)\end{array}$ & $\begin{array}{c}\mathrm{HGB} \\
(\mathrm{g} / \mathrm{dL})\end{array}$ & $\begin{array}{c}\text { Reticulocytes } \\
(\%)\end{array}$ & $\begin{array}{c}\text { Spleen } \\
\text { weight }(\%)^{\mathrm{A}}\end{array}$ & $\begin{array}{c}\mathrm{MCV} \\
(\mathrm{fL})\end{array}$ & $\begin{array}{c}\mathrm{MCH} \\
(\mathrm{pg})\end{array}$ & $\begin{array}{c}\mathrm{MCHC} \\
(\mathrm{g} / \mathrm{dL})\end{array}$ \\
$4.2^{+/+}(10)$ & $10.4 \pm 0.2$ & $51.8 \pm 0.7$ & $16.5 \pm 0.2$ & $2.5 \pm 0.1$ & $0.35 \pm 0.02$ & $49.9 \pm 0.8$ & $15.9 \pm 0.2$ & $31.9 \pm 0.4$ \\
$4.2^{+/-}(12)$ & $10.9 \pm 0.2$ & $51.4 \pm 0.7$ & $16.4 \pm 0.2$ & $2.4 \pm 0.2$ & $0.37 \pm 0.03$ & $47.5 \pm 0.7$ & $15.1 \pm 0.3$ & $31.9 \pm 0.7$ \\
$4.2^{-/-}(12)$ & $9.7 \pm 0.2^{\mathrm{B}}$ & $44.7 \pm 0.9^{\mathrm{C}}$ & $15.5 \pm 0.3$ & $5.5 \pm 0.8^{\mathrm{D}}$ & $0.57 \pm 0.04 \mathrm{C}$ & $46.3 \pm 0.7^{\mathrm{D}}$ & $16.0 \pm 0.4$ & $34.5 \pm 0.5^{\mathrm{C}}$ \\
\hline
\end{tabular}

All values $X \pm$ SEM. ${ }^{\text {AP }}$ ercentage of body weight. ${ }^{B} P<0.05$ vs. $4.2+/+.{ }^{C} P<0.001$ vs. $4.2+/+$. ${ }^{D} P<0.01$ vs. $4.2^{+/+}$. 


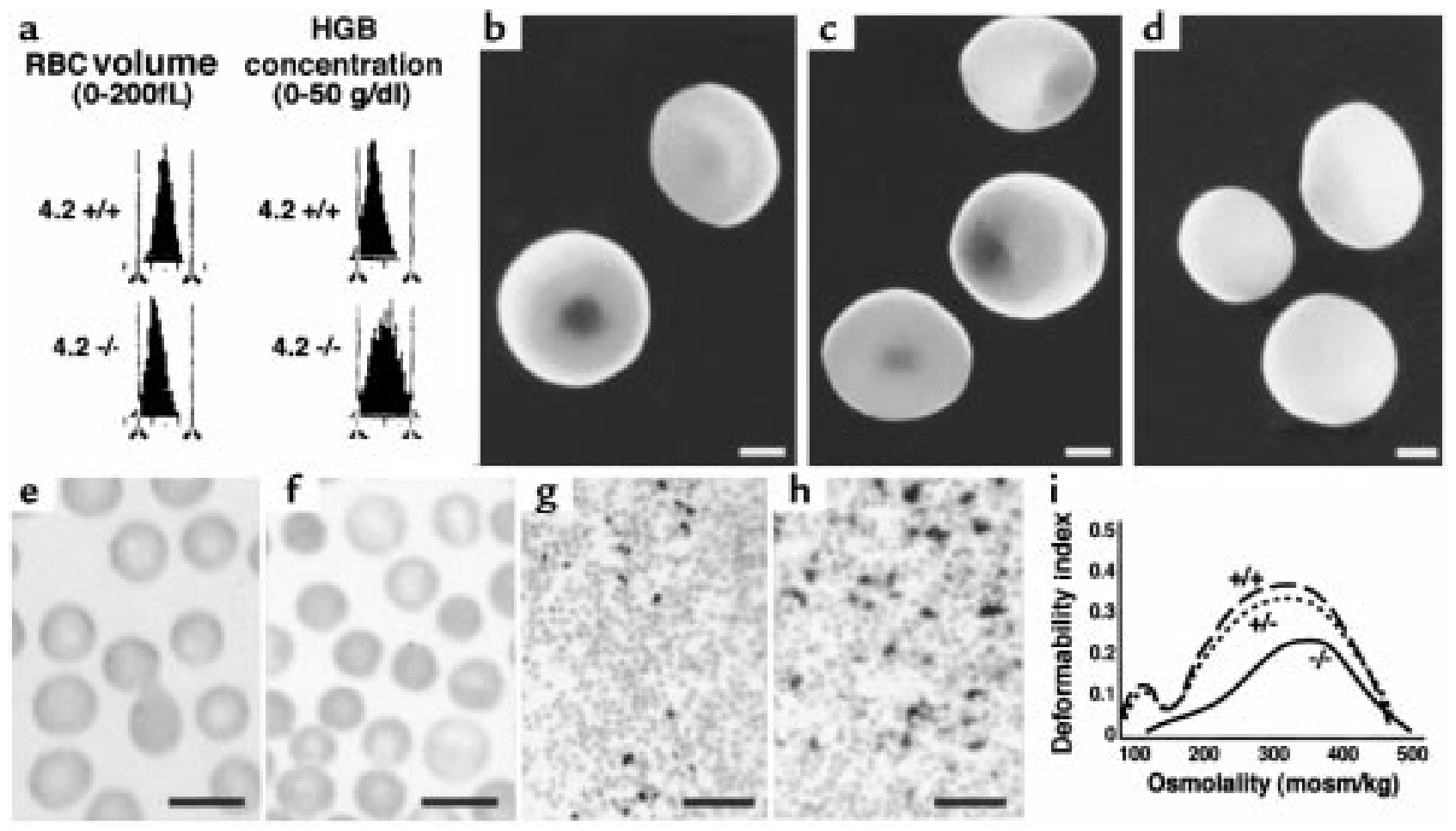

Figure 2

Protein $4.2^{-/-}$mice are mildly anemic. (a) RBC volume and hemoglobin concentration histograms obtained by automated analysis of normal $\left(4.2^{+/+}\right.$) and mutant $\left(4.2^{--}\right)$whole blood. A population of small (left-shifted volume distribution in 4.2--; bottom left) and dehydrated (right-shifted distribution in 4.2-/-; bottom right) RBCs are present in 4.2/- whole blood compared with controls. (b-d) Scanning electron microscopy. Representative photomicrographs of normal (b), heterozygous (c), and 4.2-/- (d) RBCs. Note the spherocytic shape of the 4.2-/- cells. Both normal biconcave and partially spherocytic RBCs are seen in $4.2^{+/-}$mice. Scale bar: $1 \mu \mathrm{m}$. (e and $\mathbf{f}$ ) Wright-stained peripheral blood smears from normal (e) and $4.2^{-/-}(\mathbf{f})$ mice. Note the presence of spherocytes in 4.2-deficient mice and the lack of fragmented cells. Scale bar: $10 \mu \mathrm{M}$. ( $\mathbf{g}$ and $\mathbf{h}$ ) Accumulation of iron in $4.2^{-/-}$spleen $(\mathbf{h})$ is increased compared with wild-type $(\mathbf{g})$. Scale bar: $10 \mu \mathrm{m}$. (i) Osmotic gradient ektacytometry. Representative osmotic deformability profiles of RBCs from wild-type (+/+), heterozygous (+/-), and homozygous (-/-) protein 4.2-deficient mice.

between the total activity and the activity in the presence of the specific inhibitor CKI-7 $(100 \mu \mathrm{M})$. All cytosolic kinase assays were performed in triplicate. Erythrocyte membrane-associated CKI activity was assayed according to Manno et al. (32).

\section{Results}

Gene targeting. The mouse erythrocyte protein 4.2 gene, Epb4.2, is $\sim 22 \mathrm{~kb}$ in length and consists of 13 exons (1). We replaced a fragment extending from intron 3 to exon 8 with a neomycin-resistant cassette, removing exons 4 through 7 and part of exon 8 (Figure 1a). Homozygous null mutants are not distinguishable from normal littermates by phenotype at any age. Genotyping reveals the expected Mendelian frequency of homozygous null $\left(4.2^{-/-} ; 23 \%\right)$, heterozygous $\left(4.2^{+/-} ; 51 \%\right)$, and wild-type $\left(4.2^{+/+} ; 26 \%\right)$ offspring from heterozygous mating pairs. Protein 4.2 is not detected in $4.2^{-/-}$RBC ghosts on Coomassie blue-stained SDS-PAGE gels (Figure 1b) or by Western blotting of RBC ghosts or whole-RBC lysates (Figure 1c). No protein 4.2 mRNA is detected by Northern blot analysis of $4.2^{-/}$newborn reticulocyte RNA (Figure 1d). Protein 4.2 is detected in wild-type, but not $4.2^{-/-}$, platelet lysates (Figure 1e).

We examined expression of Epb4.2 in nonerythroid tissues by RNase protection using a 295-bp fragment as probe (1). In kidney, the expected 295-bp protected fragment is detected in $4.2^{+/+}$, but not $4.2^{-/-}$, mRNA (Figure 1f). Intermediate levels are seen in $4.2^{+/-}$kidney. Unexpectedly, a 250-bp protected fragment is detected at equal intensities in kidney mRNA in all 3 groups of animals. The origin of the 250-bp fragment is unknown. However, increasing the RNase concentration during hybridization significantly lowers the intensity of the 250-bp product, but not that of the 295-bp product (Figure 1f, third panel), suggesting that the 250 -bp product derives from a related but distinct gene. RNase protection assays of brain, heart, liver, and spleen gave the same results (not shown).

Scanning densitometry of Coomassie blue-stained gels reveals a decreased protein 4.2 /spectrin ratio in $4.2^{+/-}$ RBC ghost membranes (ratio $X \pm$ SEM; $4.2^{+/+}, 0.14 \pm 0.01$ $\left.[n=3] ; 4.2^{+/-}, 0.10 \pm 0.01[n=3] ; P<0.05\right)$. We conclude that the gene-targeting event produces a null mutation in the Epb4.2 gene when homozygous and partial protein 4.2 deficiency when heterozygous .

$4.2^{-/-}$mice have mild HS. RBC counts and hematocrits (HCT) are significantly reduced in $4.2^{-/-}$mice (Table 1 ). Hemoglobin (HGB) levels do not differ significantly but are slightly lower in $4.2^{-/-}$mice. Reticulocyte percentages and spleen weights are increased approximately 2 -fold, indicating a compensatory acceleration of erythropoiesis. White blood cell counts do not differ (not shown). The mean corpuscular volume (MCV) is reduced and the MCHC is elevated (Table 1 and Figure 2a), indi- 
cating the presence of a population of small, dehydrated RBCs in $4.2^{-/-}$mice. All hematological parameters in $4.2^{+/-}$mice are normal (Table 1 ).

Peripheral blood smears and scanning electron microscopy (Figure 2, b-f) confirm the presence of spherocytes in $4.2^{-/-}$mice. Both normal biconcave RBCs and intermediate, cup-shaped cells are seen in heterozygotes. Iron staining shows increased iron deposition in the $4.2^{-/-}$spleen, indicative of increased RBC destruction (Figure 2, g and h). No iron deposition is seen in 4.2-/kidney, indicating that intravascular hemolysis is negligible (not shown). Osmotic deformability profiles confirm loss of membrane surface in $4.2^{-/-}$RBCs (Figure 2i). The maximum value of the deformability index $\left(\mathrm{DI}_{\max }\right)$, a direct measure of the mean $\mathrm{RBC}$ membrane surface area (25), is lower than normal in $4.2^{+/-} \mathrm{RBCs}$ and is further decreased in $4.2^{-/-}$RBCs. The osmolality at which the DI reaches a minimum in the hypotonic region of the gradient $\left(\mathrm{O}_{\mathrm{min}}\right)$, a measure of the average surface area/volume ratio of the RBCs, is higher than normal in $4.2^{-/-}$RBCs. We conclude that 4.2 deficiency results in RBC membrane loss and mild HS.

$4.2^{-/-}$RBCs are band 3 deficient. The band 3 content of 4.2-/- RBC membranes appears to be decreased on SDSPAGE gels (Figure 1b) and Western blots (Figure 3a). The band $3 /$ spectrin ratio, estimated by scanning densitometry of Coomassie blue-stained gels, is decreased in $4.2^{-/-}$ RBCs (ratio $X \pm \mathrm{SEM} ; 4.2^{+/+}, 1.19 \pm 0.07[n=3] ; 4.2^{-/-}, 1.00$ $\pm 0.03[n=5] ; P<0.01]$. The DIDS concentration required to maximally inhibit sulfate influx is decreased to $\sim 70 \%$ of normal in $4.2^{-/-}$RBCs (Figure $3 \mathrm{~b}$ ). The maximal inhibitory DIDS concentration directly correlates to the number of band 3 molecules, confirming band 3 deficiency in the absence of protein 4.2. Net DIDS-sensitive sulfate influx is decreased to $\sim 60 \%$ of wild-type (Figure 3c) in $4.2^{-/-}$RBCs. In both normal and 4.2-/RBCs, $<10 \%$ of band 3 molecules were laterally mobile ( $n$ $=6$ and 14 cells, respectively). The diffusion coefficient of the mobile band 3 molecules could not be estimated reliably for this degree of lateral immobilization. The prebleach fluorescence values of eosin-labeled $4.2^{-/-}$ RBCs were $69 \%$ of those of normal RBCs, in agreement with the results above indicating that band 3 is $30 \%$ decreased in $4.2^{-/-}$RBCs.

In $4.2^{+/-}$RBCs, the band $3 /$ spectrin ratio is also decreased compared with $4.2^{+/+}(1.12 \pm 0.04[n=3], P>$ $0.05)$, and the net DIDS-sensitive sulfate influx is $\sim 80 \%$ of normal (Figure 3c).

4.2- $2^{--}$RBC membrane skeleton architecture and spectrin content are normal. Despite the absence of protein 4.2 and partial band 3 deficiency, a normal membrane skeleton is assembled in 4.2-/- RBCs. Electron microscopy shows a qualitatively normal, intact skeleton architecture (Figure 4, $a$ and b). By SDS-PAGE and Western blotting of RBC ghost membranes, normal amounts of spectrin, ankyrin, protein 4.1, p55, and GPC are seen in $4.2^{-/-}$ RBCs (Figures $1 \mathrm{~b}$ and 3a). In low-ionic-strength Triton $\mathrm{X}-100$-extracted RBC membranes, the equivalent of pure, isolated membrane skeletons (so-called Triton "shells"), normal amounts of $\alpha$ - and $\beta$-spectrin and ankyrin are present in $4.2^{-/-}$skeletons (Figure $4 \mathrm{c}$ ). However, increased levels of protein 4.1 are seen reproducibly in $4.2^{-/-}$Triton shells prepared in both 0 (Figure $4 c$ ) and $150 \mathrm{mM}$ (not shown) salt concentrations.

Previous studies revealed a near-normal membrane skeleton, qualitatively and quantitatively, in mouse band 3-null RBCs (6). Band 3-null RBC membranes are, however, $\sim 50 \%$ deficient in IMPs, and the IMPs that remain are clustered (Figure 4, d and e). Similar loss and clustering of IMPs, albeit less extreme, are seen in 4.2\% RBCs (Figure $4 \mathrm{f}$. These observations support the hypothesis that membrane loss in 4.2-/- RBCs, as in band 3-null RBCs, results from destabilization of the membrane due to a lack of horizontal lipid-protein interactions in those areas that are relatively devoid of integral membrane proteins (as visualized by the IMP distribution) within the bilayer.
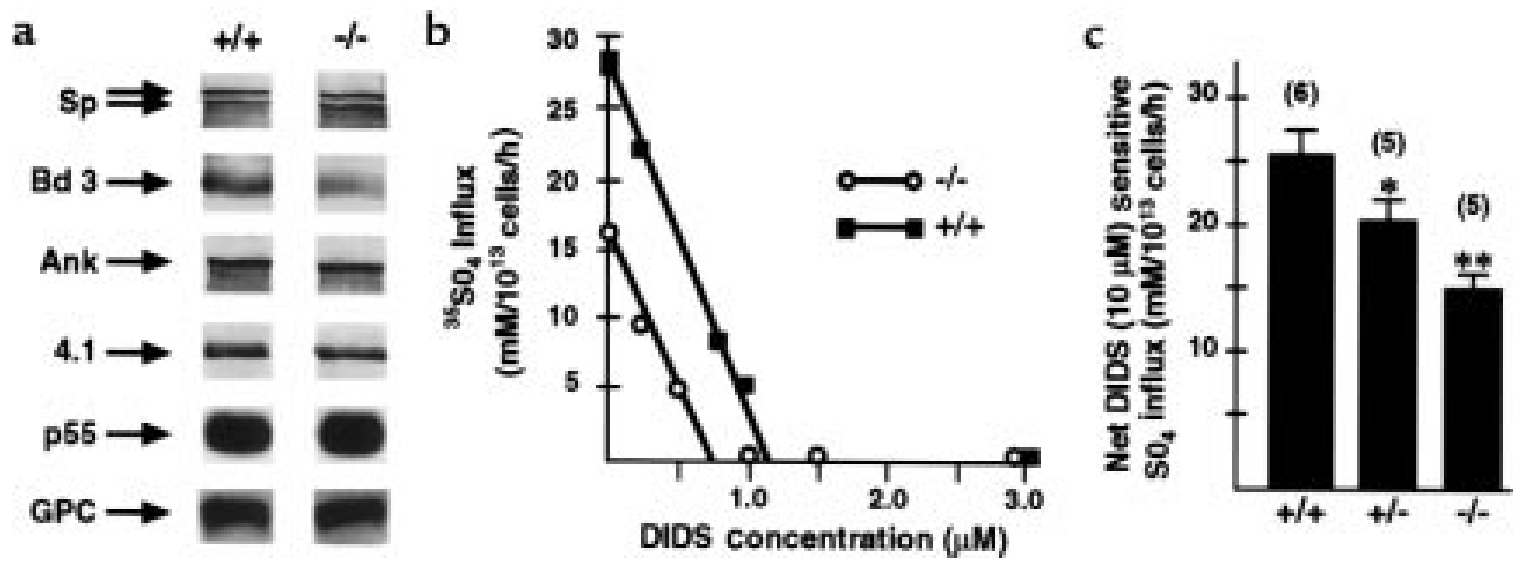

Figure 3

Partial band 3 deficiency in 4.23 (Bd 3), ankyrin (Ank), protein 4.1 (4.1), p55, and glycophorin C (GPC) in normal (+/+) and 4.2-null (-/-) RBC membrane ghosts. p55 and GPC were detected using chemiluminescence; Sp, Bd 3, Ank, and protein 4.1 were detected using alkaline phosphatase-labeled secondary antibody. Each lane contains either equivalent amounts of ghost proteins ( $5 \mu \mathrm{g}$ : bd 3 and $4.1 ; 20 \mu \mathrm{g}$ : p55 and GPC) or cells $\left(5 \times 10^{7}\right.$ total cells: Sp and Ank). Note the decrement in band 3 in null (-/-) vs. normal (+/+) RBC membrane ghosts. (b) The maximal inhibitory DIDS concentration in 4.2-/- RBCs is decreased to $\sim 70 \%$ of $4.2^{+/+}$, confirming reduction of band 3. (c) Red blood cell anion transport. DIDS-sensitive sulfate transport $(X \pm S E M)$ in $4.2^{-/-}$ and $4.2^{+/-}$RBCs is decreased to $\sim 60 \%$ and $\sim 80 \%$, respectively, of $4.2^{+/+}$RBCs. ${ }^{*} P<0.05$ vs. $4.2^{+/+} .{ }^{* *} P<0.01$ vs. $4.2^{+/+}$. 
Cation content and transporter activities in $4.2^{-/-}$RBCs. The $\mathrm{Na}^{+}$content is increased and $\mathrm{K}^{+}$content decreased in $4.2^{-/-}$RBCs (Figure 5, $\mathrm{a}$ and $\mathrm{b}$ ). The absolute $\mathrm{K}^{+}$loss exceeds the $\mathrm{Na}^{+}$gain, resulting in dehydration. No significant differences were seen in $4.2^{+/-}$RBCs compared with wild-type. To elucidate possible mechanisms involved in producing the observed cation alterations, we measured cation transporter activities and determined the passive $\mathrm{Na}^{+}$and $\mathrm{K}^{+}$permeabilities in $4.2^{-/-}$and $4.2^{+/-}$ RBCs compared with wild-type RBCs.
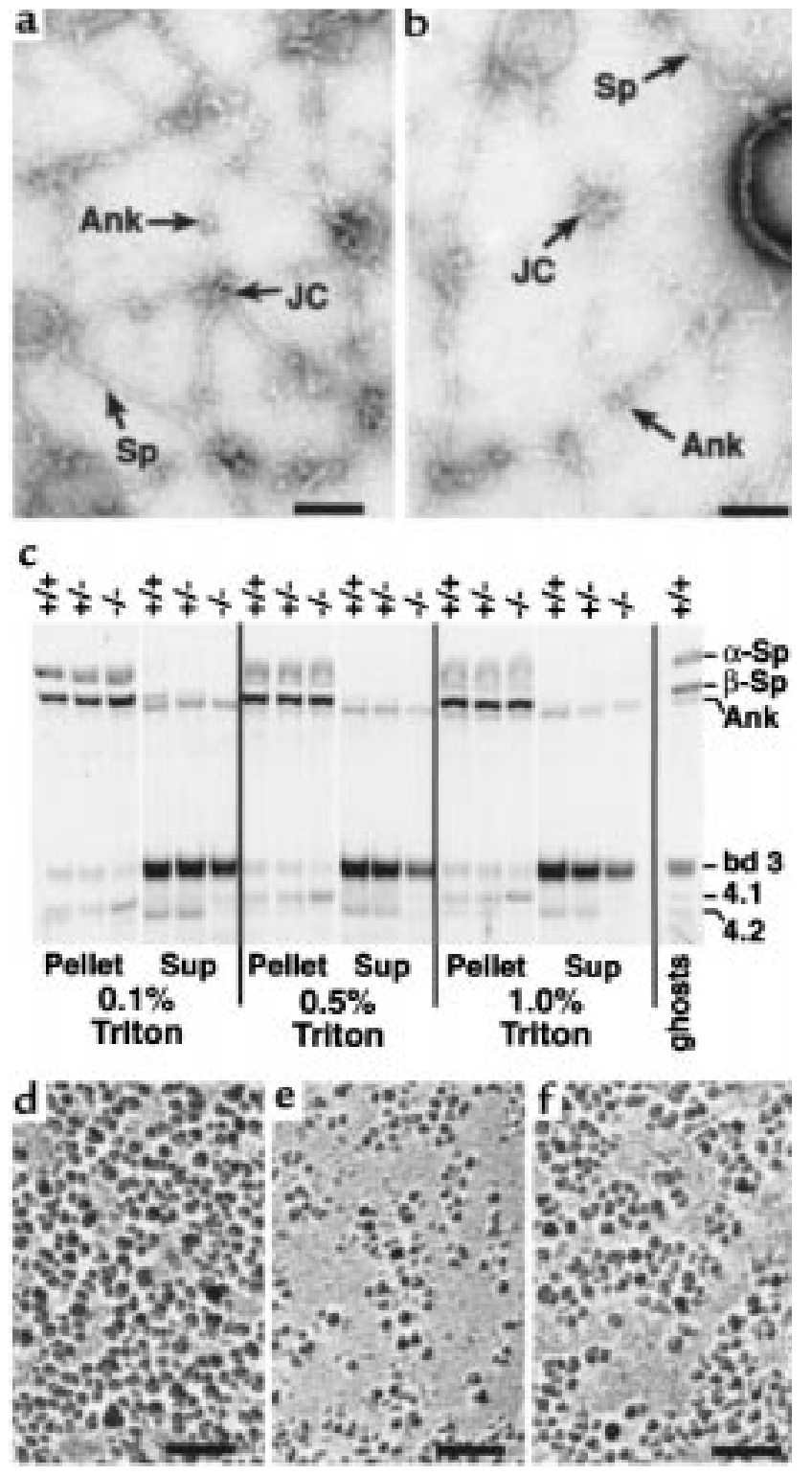

Figure 4

Ultrastructure of RBC membrane skeletons. (a and b) Negatively stained, spread membrane skeletons from normal (a) and protein $4.2^{-/-}$(b) RBCs. Sp, spectrin filament. JC, junctional complexes. Ank, ankyrin. Scale bar: $100 \mathrm{~nm}$. (c) Triton X-100-extracted RBC membranes. Ten micrograms of normal $(+/+)$, heterozygous (+/-), and 4.2-null (-/-) RBC ghost membranes was extracted in $0.1,0.5$, or $1.0 \%$ Triton $X-100$. The pellet and supernatant (sup) fractions were resolved on a $3.5-17 \%$ Fairbanks gradient gel and stained with Coomassie blue. Sp, spectrin. Ank, ankyrin. bd 3, band 3. 4.1, protein 4.1. 4.2, protein 4.2. (d-f) IMPs in normal (d), band 3-null (e), and 4.2-null (f) RBCs. Note the presence of enlarged particle-free areas in band 3- and 4.2-null RBCs. Scale bar: $100 \mathrm{~nm}$.
The maximal rates of the $\mathrm{Na}-\mathrm{K}$ pump are identical among the 3 genotypes (Figure $5 \mathrm{c}$ ). There is a small but significant $(P<0.05)$ increase in the activity of the $\mathrm{K}-\mathrm{Cl}$ cotransporter, defined as the Cl-dependent efflux (efflux in the presence of hypotonic $\mathrm{NaCl}$ minus that in $\mathrm{Na}$ sulfamate), in $4.2^{-/-}$RBCs compared with normal RBCs (Figure 5d). Significant increases in the activities of the bumetanide-sensitive $\mathrm{Na}-\mathrm{K}-2 \mathrm{Cl}$ cotransporter and the calcium-stimulated $\mathrm{K}^{+}$efflux (Gardos) channel are seen in $4.2^{-/-}$RBCs, with intermediate values seen in $4.2^{+/-}$ RBCs (Figure 5, e and $\mathrm{f}$ ). An even more dramatic increase is seen in the activity of the $\mathrm{Na} / \mathrm{H}$ exchanger in $4.2^{-/-}$ RBCs (Figure $5 \mathrm{~g}$ ). A small increase in the passive $\mathrm{Na}^{+}$permeability is present in 4.2-/- RBCs; no differences are seen in the passive $\mathrm{K}^{+}$permeability (Figure $5 \mathrm{~h}$ ).

To determine if the increased $\mathrm{Na} / \mathrm{H}$ exchange and $\mathrm{Na}$ $\mathrm{K}-2 \mathrm{Cl}$ cotransport are due to altered regulation of these transporters, we studied the effect of volume changes by changing the osmolarity of the flux medium. As shown in Figure 6, the increased transport activities and passive $\mathrm{Na}$ permeability observed in $4.2^{-/-} \mathrm{RBCs}$ are due to increased sensitivity to cell shrinkage.

Mechanism of increased cation transport: a potential role for phosphorylation. Increased $\mathrm{Na}-\mathrm{K}-2 \mathrm{Cl}$ cotransporter and $\mathrm{Na} / \mathrm{H}$ exchanger activities correlate with a net increase in phosphorylation in a variety of cell types (33-36). To assess the phosphorylation status of 4.2-deficient RBCs, we measured the activities of the major RBC kinases. Cytosolic PKC is significantly decreased in 4.2-deficient RBCs (Table 2). Western blot analyses show decreased PKC- $\alpha$ and PKC- $\beta$ I isoforms but normal PKC- $\beta$ II (Figure $7 \mathrm{a}$ ) in $4.2^{-/-}$RBCs. Cytosolic protein kinase A (PKA) activity is increased in $4.2^{-/-} \mathrm{RBCs}$ (Table 2 ). Consistent with the observed PKC and PKA changes, basal phosphorylation is increased and PMA-stimulated phosphorylation is reduced in $4.2^{-/-} \mathrm{RBC}$ membranes compared with normal (Figure $7 \mathrm{~b}$ ). In addition, cytosolic casein kinase I (CKI) activity is normal in 4.2-deficient RBCs, whereas cytosolic CKII activity is decreased (Table 2). The functional significance of the latter activity, if any, is unknown.

The activity of the major RBC membrane-bound kinase, CKI, was measured by incubating ghost membranes in the presence of $\left[\gamma^{32} \mathrm{P}\right] \mathrm{ATP}$ and excising and counting phosphorylated proteins identified by autoradiography. In 2 separate experiments, the counts obtained from $4.2^{-/-}$membranes were significantly greater than wild-type membranes and slightly greater in heterozygous membranes. The counts obtained in one experiment are given in Table 2.

Nonerythroid pathology. Immunologically related protein 4.2 has been localized previously to platelet vesicles with the characteristics of early lysosomes, but it is absent from other intracellular organelles, including dense bodies, alpha granules, mitochondria, and Golgi (37). We show that protein 4.2 is present in normal platelets and absent from $4.2^{-/-}$platelets (Figure 1e). This observation indicates that protein 4.2 in platelets is a product of the same gene (Epb4.2) as is erythrocyte protein 4.2. However, no abnormality of platelet number is seen in 4.2-deficient mice (platelet counts $\times 10^{3} / \mu \mathrm{L} ; X \pm \mathrm{SEM} ; n=6$ : $\left.4.2^{+/+}, 1,177 \pm 108 ; 4.2^{+/-}, 1,150 \pm 70 ; 4.2^{-/-}, 1,112 \pm 130\right)$, 
and bleeding times do not significantly differ among the 3 groups of mice (not shown).

Histological examination of brain, spinal cord, heart, lung, liver, kidney, intestine, and muscle reveals no overt pathological changes in protein 4.2-deficient mice at 2 or 9 months of age (not shown).

\section{Discussion}

Mechanism of membrane loss in HS. Two hypotheses regarding the mechanism of membrane loss in HS have been proposed (2). In the first, the lipid bilayer is stabilized by interactions with the underlying spectrin skeleton. Unsupported, spectrin-deficient areas vesiculate, leading to spherocytosis. In the second, the "lipid-anchoring" hypothesis, the bilayer is stabilized by horizontal interactions between lipids and neighboring integral membrane proteins in the bilayer. Band 3 would be expected to contribute greatly to these lipid-protein interactions, as there are $\sim 1.2 \times 10^{6}$ band 3 molecules per cell, each containing 12 transmembrane loops (38). Indeed, the primary evidence for the lipid-anchoring hypothesis arose from the observation that band 3 deficiency in humans causes HS, yet the membrane skeleton spectrin content and structure are normal (2). Further evidence was provided by targeted deletion of band 3 in mice. Band 3-null mice are severely anemic and their RBCs shed membrane copiously, yet the membrane spectrin content is normal and

\section{Table 2}

Erythrocyte kinase activities

\begin{tabular}{cccccc}
\hline $\begin{array}{c}\text { Genotype Cytosolic } \\
\text { PKC }\end{array}$ & $\begin{array}{c}\text { Cytosolic } \\
\text { PKA }\end{array}$ & $\begin{array}{c}\text { Cytosolic } \\
\text { CKI }\end{array}$ & $\begin{array}{c}\text { Cytosolic } \\
\text { CKII }\end{array}$ & $\begin{array}{c}\text { Membrane } \\
\text { CK1 }(\mathrm{cpm})\end{array}$ \\
$4.2^{+/+}$ & $18.44 \pm 0.77$ & $14.34 \pm 0.61$ & $25.56 \pm 0.40$ & $16.09 \pm 0.40$ & 4,034 \\
$4.2^{+/-}$ & $11.52 \pm 0.21^{\mathrm{A}}$ & $13.63 \pm 0.31$ & $26.27 \pm 0.68$ & $14.83 \pm 0.68$ & 6,859 \\
$4.2^{-/-}$ & $10.26 \pm 0.40^{\mathrm{A}}$ & $23.94 \pm 0.06^{\mathrm{B}}$ & $26.25 \pm 1.67$ & $7.04 \pm 1.67^{\mathrm{B}}$ & 12,685
\end{tabular}

Cytosolic enzyme activities are represented by picomolars of ${ }^{32} \mathrm{P}$ incorporated per minute per milligram of protein. All values $X \pm$ SEM for 3 independent determinations. AP $<0.001$ vs. $4.2^{+/+}$. B $P<0.01$ vs. $4.2^{+/+}$.

the skeleton architecture is intact (6).

This study provides further evidence for lipid anchoring as a significant determinant of membrane stability. Protein $4.2^{-/-}$RBCs shed membrane and become spherocytic in the presence of a normal membrane skeleton with normal spectrin content. IMP-free areas are clearly visible, suggesting that portions of the RBC membrane are relatively protein free. Presumably, the loss of IMPs in $4.2^{-/-}$RBCs occurs secondary to partial band 3 deficiency (although we cannot strictly rule out other integral protein contributions); as a result of band 3 loss, lipid anchoring is compromised and unsupported lipids lost, resulting in spherocytosis. Spectrin- and ankyrindeficient red cells (17) could also become spherocytic by this mechanism. Since spectrin filaments limit the later- a

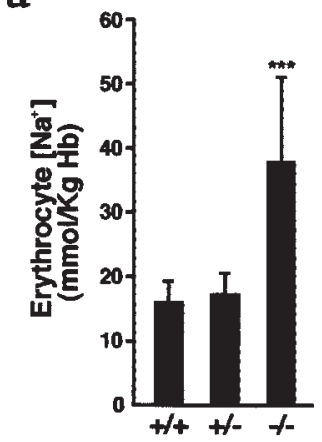

e

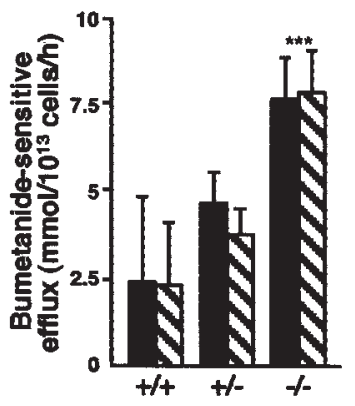

b

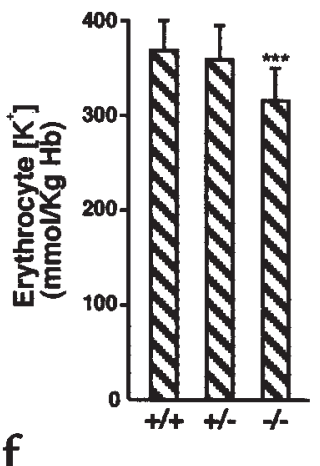

c

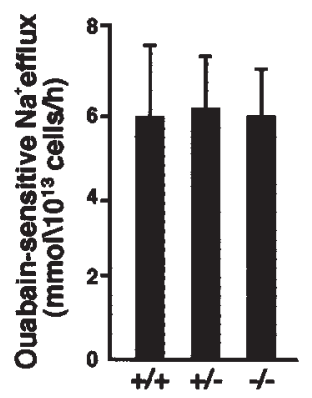

g

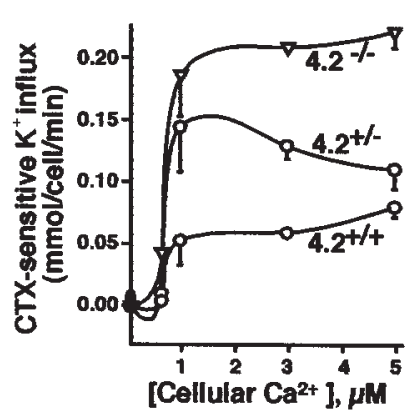

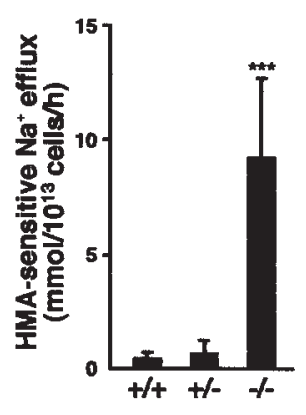

d

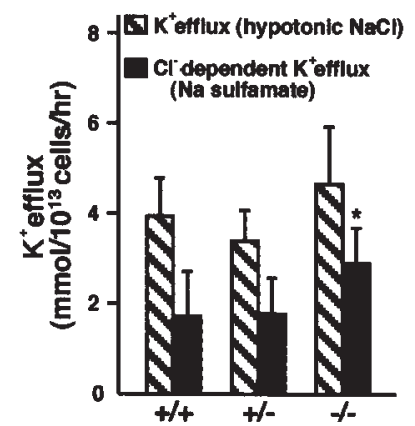

h

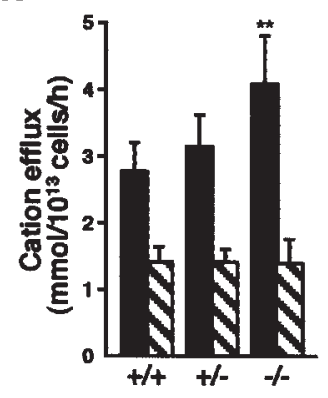

Figure 5

Cation content and transporter activities of 4.2-deficient RBCs. $\mathrm{Na}^{+}(\mathbf{a})$ and $\mathrm{K}^{+}(\mathbf{b})$ content of RBCs. The $\mathrm{Na}^{+}$content is significantly increased and the $\mathrm{K}^{+}$content is significantly decreased in 4.2-null (-/-) RBCs compared with normal (+/+) RBCs. (c) Maximal activity of the RBC Na-K pump. (d) Chloride-dependent $\mathrm{K}-\mathrm{Cl}$ cotransporter activity. Hatched bars show $\mathrm{K}$ efflux in the presence of $260 \mathrm{mOsm} \mathrm{NaCl}$. Filled bars show $\mathrm{Cl}^{-}$ dependent $\mathrm{K}^{+}$efflux (difference between efflux in $\mathrm{NaCl}$ and $\mathrm{Na}$ sulfamate media, $260 \mathrm{mOsm}$ ). (e) Bumetanide-sensitive $\mathrm{Na}-\mathrm{K}-2 \mathrm{Cl}$ cotransporter activity. (f) Gardos channel activity. (g) Amiloride-sensitive $\mathrm{Na} / \mathrm{H}$ exchanger activity. (h) Passive permeability for $\mathrm{Na}^{+}$and $\mathrm{K}^{+}$in the presence of 1 $\mathrm{mM}$ ouabain, $10 \mu \mathrm{M}$ bumetanide, and $10 \mu \mathrm{M}$ amiloride. Filled bars, $\mathrm{Na}^{+}$efflux. Hatched bars, $\mathrm{K}^{+}$efflux. The observed changes in $\mathrm{Na}-\mathrm{K}-2 \mathrm{Cl}$ cotransporter and $\mathrm{Na} / \mathrm{H}$ exchanger rates account for the majority of the cation concentration differences seen in $4.2^{-/-}$cells. All values $X \pm \mathrm{SD}$. ${ }^{*} P<0.05$ vs. $4.2^{+/+}$. ${ }^{*} P<0.01$ vs. $4.2^{+/+} .{ }^{*}{ }^{*} P<0.001$ vs. $4.2^{+/+}$. 

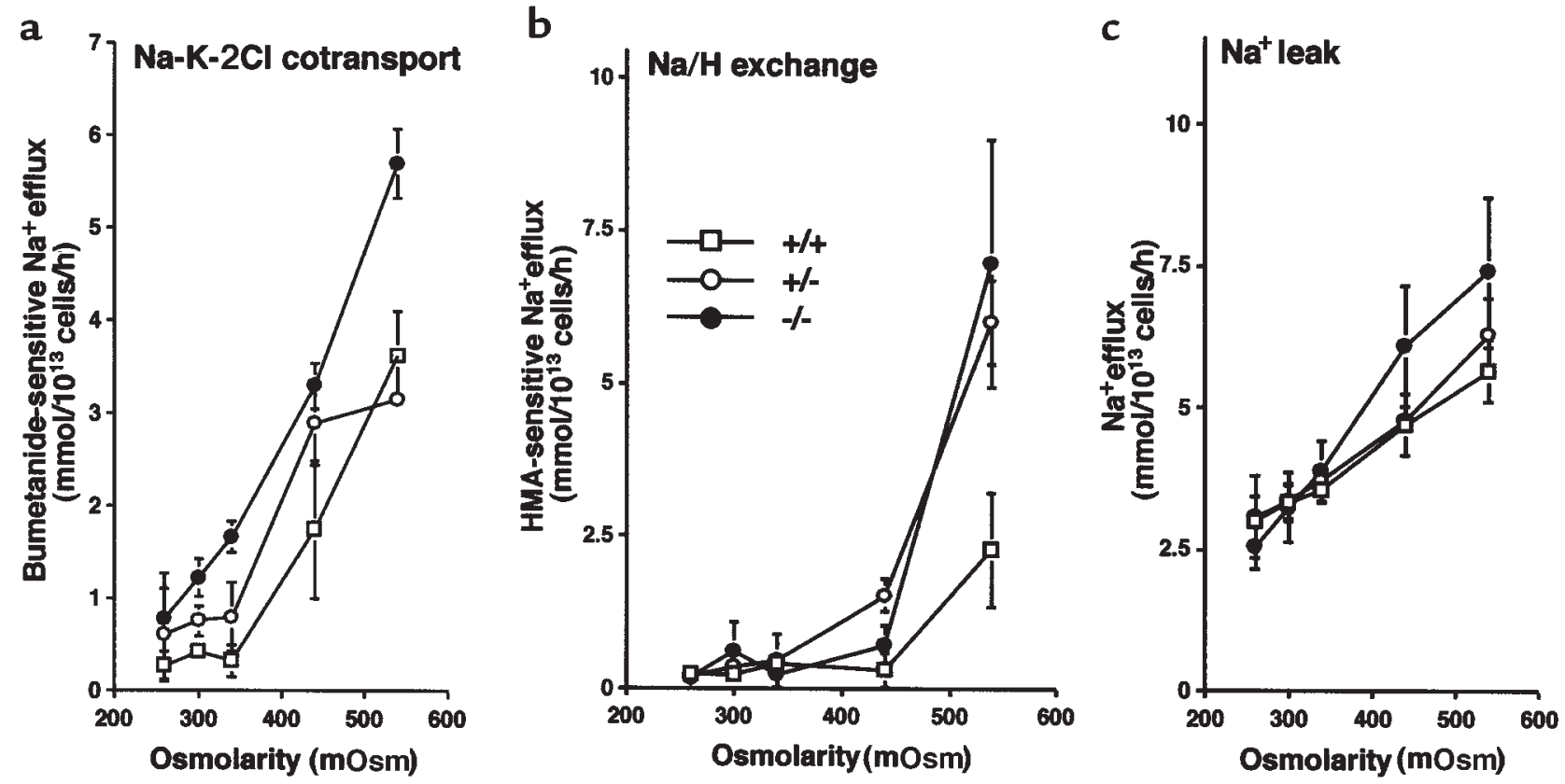

Figure 6

Effect of cell shrinkage on cation transport in 4.2-deficient RBCs. Influence of cell volume on the activities of $\mathrm{Na}-\mathrm{K}-2 \mathrm{Cl}$ cotransport (a), $\mathrm{Na} / \mathrm{H}$ exchange (b), and $\mathrm{Na}^{+}$passive permeability (c).

al movement of band 3 molecules (39), a decrease in spectrin would allow band 3 molecules to cluster, leading to vesiculation. Hence, loss of lipid anchoring conceivably represents the final common pathway leading to HS in a variety of membrane skeletal protein defects.

Protein 4.2 interactions within the membrane skeleton. The studies reported here provide insights into the interactions of protein 4.2 within the membrane. The maximal DIDS inhibitory concentration is decreased to $70 \%$ of normal, confirming the decrement in the number of band 3 molecules in 4.2/- RBCs. Previous studies suggested that protein 4.2 negatively regulates band 3 anion transport activity. In band 3 reconstituted liposomes, anion transport activity increased with decreasing levels of bound protein 4.2 (9). In human 4.2 deficiency, normal DIDS maximal inhibitory concentration was seen, yet band 3-mediated anion transport activity was dramatically increased (7). These observations lead to the hypothesis that protein 4.2 exerts an allosteric effect upon binding to the cytoplasmic domain of band 3, which inhibits its anion transport function. Our data do not support an inverse correlation between membrane protein 4.2 content and anion transport activity in mouse RBCs, as the number of band 3 molecules in the membrane is decreased by $30 \%$, and the overall anion transport activity by $40 \%$, in the absence of protein 4.2 .

As reported previously (26), the lateral mobility of band 3 in normal mouse RBCs is markedly restricted. In normal RBCS, $\sim 40 \%$ of band 3 molecules are thought to be laterally immobilized by high-affinity (i.e., long-lived) interactions between ankyrin and band 3 tetramers, whereas $\sim 50 \%$ of band 3 molecules are believed to be immobilized by steric hindrance between the cytoplasmic domain of band 3 and the spectrin-based membrane skeleton (26). The concordance between the band 3 lat- eral mobility values in normal and 4.2-/- RBCs suggests that these interactions between band 3 and the membrane skeleton are preserved in 4.2-null RBCs. These data do not exclude the possibility, however, that weakened interactions between a fraction of band 3 molecules and the membrane skeleton are responsible for the partial loss of band 3 as protein 4.2-deficient RBCs develop in the bone marrow.

Rotational mobility data could address the extent of band 3 mobility restriction more sensitively than could the lateral mobility data presented here (26). Unfortunately, signal-to-noise considerations have prevented us from obtaining meaningful data from polarized fluorescence depletion experiments on $4.2^{-/-}$RBCs. In future studies, we plan to use a combination of biochemical and biophysical techniques to investigate quantitatively the degree of interaction between the membrane skeleton and the various oligomerization states of band 3 in 4.2-/- RBCs.

By SDS-PAGE analysis, the protein 4.1 content of $4.2^{-/-}$ Triton shells is significantly increased compared with normal Triton shells. In RBC ghost membranes, however, increased protein 4.1 is much less (if at all) apparent (Figures $1 \mathrm{~b}$ and $3 \mathrm{a}$ ). RBC ghosts include Triton-soluble GPC, a major protein 4.1 ligand. The protein 4.1 and protein 4.2 binding sites have been localized to nearby sites on the cytoplasmic domain of band 3 (40). Possibly, in the absence of protein 4.2, additional binding sites for protein 4.1 on band 3 are exposed, and protein 4.1 bound previously to GPC prior to extraction with Triton $\mathrm{X}-100$ becomes bound to these additional sites.

Both protein 4.1 and GPC deficiency in humans alter red cell shape and mechanical properties (41, 42). Mechanical instability of GPC-deficient RBCs, however, is due to secondary deficiency of protein 4.1 and can be 
restored by reconstituting the membrane with protein 4.1 or with the protein 4.1 spectrin-actin binding domain (43). Neither GPC nor protein 4.1 is diminished in $4.2^{-/-}$ RBC membranes. Conceivably, however, a change in location of protein 4.1 could contribute to the $4.2^{-/-}$phenotype. We feel this is unlikely based upon the following observations. Dissociation of protein 4.1 from band 3 decreases membrane deformability in studies using inside-out vesicles, presumably by increasing band 3ankyrin interactions that, in turn, reduce the flexibility of spectrin filaments (44). Based on these data, increased protein 4.1-band 3 linkages would not be expected to decrease membrane deformability. Marked fragmentation, decreased GPC (16\% of normal), and absent p55 are observed in protein 4.1-null mouse RBCs (45). Protein 4.2-/- RBCs, however, show normal levels of p55 and GPC and are not fragmented, suggesting that the protein 4.1GPC-p55 ternary complex is intact. It seems unlikely, therefore, that altered location of protein 4.1 contributes to the 4.2-null phenotype. However, as the relative distribution of protein 4.1 bound to band 3 and GPC in the intact $4.2^{-/-} \mathrm{RBC}$ is unknown, additional analyses (e.g., pulse-chase analyses, binding studies) of the interactions of the major membrane skeleton components of $4.2^{-/-}$ RBCs will be required to definitively determine the role of protein 4.1, if any, in the 4.2-/- phenotype.

Protein 4.2 in nonerythroid cells. Proteins cross-reactive with protein 4.2 antisera have been detected in platelets, melanocytes, kidney, liver, heart, and brain $(19,46,47)$. Protein 4.2 mRNA has been detected upon prolonged exposure of Northern blot analyses of kidney, liver, heart, and brain $(19,47)$. In this study, RNase protection assays detected an unexpected protected fragment in $4.2^{-/-}$tissues. However, we detected no pathology in the major organs of $4.2^{-/-}$mice, suggesting that their phenotype is limited to erythroid cells. Together, these observations suggest that a protein 4.2 homologue encoded by a distinct gene is present in nonerythroid tissues.

We provide evidence that the erythrocyte protein 4.2 gene (Epb4.2) is also present in platelets, but no platelet dysfunction is seen. Additional, more quantitative analyses will be required to elicit the role of protein 4.2 in platelets.

Protein 4.2 and cation transport. RBC dehydration due to altered cation concentration is characteristic of membrane skeleton defects in humans and mice. A markedly accelerated $\mathrm{Na}-\mathrm{K}$ pump rate and increased passive permeability were demonstrated in 2 different mouse mutations, spectrin-deficient sph mice and ankyrin-deficient $n b$ mice (8). In both mutants, however, the activities of the bumetanide $\mathrm{Na}-\mathrm{K}-2 \mathrm{Cl}$ and $\mathrm{K}-\mathrm{Cl}$ cotransporters were normal, indicating that $\mathrm{K}^{+}$loss and $\mathrm{Na}^{+}$gain were not mediated by these transporters. Hence, it was concluded that the membrane skeleton plays a role in maintaining the RBC permeability barrier, and loss of membrane skeleton integrity results in increased passive permeability. As reported here, protein 4.2-deficient RBCs show normal $\mathrm{Na}-\mathrm{K}$ pump activity, markedly increased $\mathrm{Na}-\mathrm{K}$ $2 \mathrm{Cl}$ cotransporter, $\mathrm{Na} / \mathrm{H}$ exchanger and Gardos channel activities, and a moderate increase in $\mathrm{K}-\mathrm{Cl}$ cotransport activity. The changes in cation transport activities in 4.2-/- RBCs cannot be attributed to the presence of younger cells. Na-K pump activity is increased in reticu- locytes but shows no changes in $4.2^{-/-}$RBCs, which may indicate that 4.2 deficiency blunts its upregulation in reticulocytes and earlier erythroid precursor cells. Moreover, $s p h$ and $n b$ homozygous mice are characterized by much greater numbers ( $>50 \%)$ of circulating reticulocytes than are $4.2^{-/-}$mice, yet $\mathrm{K}-\mathrm{Cl}$ and $\mathrm{Na}-\mathrm{K}-2 \mathrm{Cl}$ cotransporter activities are normal in these mutants (8). Hence, markedly different cation transport alterations occur in 4.2 deficiency compared with both spectrin and ankyrin deficiency in the mouse, suggesting that specific membrane skeleton components regulate, directly or indirectly, the activity of specific cation transporters or a subset of cation transporters.

The reduced $\mathrm{K}^{+}$and increased $\mathrm{Na}^{+}$contents of $4.2^{-/-}$ RBCs can be attributed to increased $\mathrm{Na}^{+}$permeability and $\mathrm{K}-\mathrm{Cl}$ cotransport. Increased $\mathrm{Na}-\mathrm{K}-2 \mathrm{Cl}$ cotransport, which induces net loss of $\mathrm{Na}^{+}$and $\mathrm{K}^{+}$, and $\mathrm{Na} / \mathrm{H}$ exchange, which induces a net gain of $\mathrm{Na}^{+}$, may also contribute to the altered cation composition of $4.2^{-/-}$RBCs. Protein 4.2/- RBCs also demonstrate an abnormal regulation of cation transport by cell volume. Cell shrinkage induces a more prominent activation of $\mathrm{Na} / \mathrm{H}$ exchange and $\mathrm{Na}-\mathrm{K}-2 \mathrm{Cl}$ cotransport in $4.2^{-/-} \mathrm{RBCs}$ compared with controls. The increased passive $\mathrm{Na}^{+}$permeability of $4.2^{-/-}$ RBCs is dependent on cell shrinkage as well (Figure 6).

The maximal rate of the Na-K pump corresponds to the number of pump sites per cell $(48,49)$ and is unchanged in $4.2^{-/-} \mathrm{RBCs}$, indicating that there is no compensatory increase in the number of pumps per cell. However, the $4.2^{-/-}$red cell is in a different steady state compared with normal control cells. In normal cells, the activity of a fixed number of pumps depends on the internal $\mathrm{Na}^{+}$level (50);

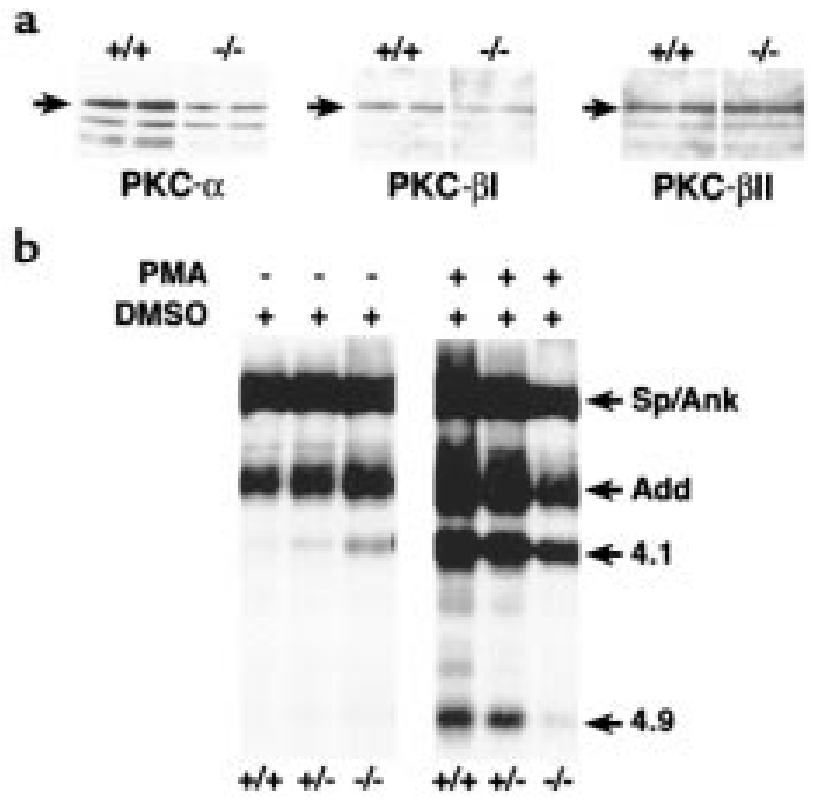

\section{Figure 7}

PKC isozyme levels and phosphorylation of membrane skeleton proteins in $4.2^{-/-}$RBCs. (a) Western blots of PKC isozymes in RBCs. Each lane contains equivalent amounts of cytosolic protein from 4.2-null (-/-) and normal $(+/+)$ RBCs. Left, PKC- $\alpha$; middle, PKC- $\beta$ I; right, PKC- $\beta I I$. (b) Basal and PMA-stimulated phosphorylation of RBC membrane skeleton proteins in normal and protein 4.2-deficient RBCs. Sp/Ank, spectrin and ankyrin. Add, adducin. 4.1, protein 4.1. 4.9, protein 4.9. 
increased $\mathrm{Na}^{+}$permeability (inward leak) increases the activity of the Na-K pump, balancing the increased $\mathrm{Na}^{+}$ leak. In 4.2-/- $\mathrm{RBCs}$, the $\mathrm{Na}^{+}$concentration remains elevated, despite a normal number of pumps per cell; i.e., $4.2^{-/-}$red cell pump activity does not respond to the same level of internal $\mathrm{Na}^{+}$as do normal cells.

In a recent study of human HS patients, similar cation transport alterations were reported regardless of the underlying membrane skeleton defect (7). Increased Na$\mathrm{K}$ pump activity and passive cation permeabilities, decreased $\mathrm{K}-\mathrm{Cl}$ cotransporter activity, and normal $\mathrm{Na}-\mathrm{K}$ $2 \mathrm{Cl}$ cotransporter and $\mathrm{Na} / \mathrm{H}$ exchanger activities were reported in patients with combined spectrin and ankyrin deficiency, band 3 deficiency, and 4.2 deficiency. These findings are markedly different than those reported in this study. One explanation may be that cation transport regulatory mechanisms differ in human and mouse RBCs. A potential molecular basis for transporter regulation differences between species has been identified in the case of the $\mathrm{K}-\mathrm{Cl}$ cotransporter. Human and mouse $\mathrm{K}-\mathrm{Cl}$ cotransporters share $96 \%$ amino acid conservation, but important consensus binding sites for PKC and CKII phosphorylation that are present in human cDNA are missing in the mouse (51).

The contribution of partial band 3 deficiency to $4.2^{-/-}$ mouse RBC cation transport is unknown. In band 3-null mice, protein 4.2 is also totally deficient, making it impossible to distinguish the relative band 3-protein 4.2 contributions to transporter activities using the band 3-null mouse model (6). However, in a recently described dominant band 3 mutation in humans, band 3 campinas (52), $\mathrm{RBC} \mathrm{Na} / \mathrm{H}$ exchange is increased 3- to 6-fold, while in other, unrelated cases of band 3 deficiency, $\mathrm{Na} / \mathrm{H}$ exchanger activity is unchanged. Notably, the band 3 campinas mutation results in skipping of exon 8 , leading to a frameshift mutation and a premature stop codon at amino acid 203 in the cytoplasmic domain. Hence, it can be predicted that bound protein 4.2 is decreased in these patients, leading to speculation that changes in the $\mathrm{Na} / \mathrm{H}$ exchanger activity (and perhaps other transporters) in band 3 deficiency depends on the specific mutation and may be related to changes in membrane protein 4.2 content. To test this hypothesis in the mouse, band 3 knock-in experiments, or a similar strategy in which substitutions in the binding site for protein 4.2 are made, are required.

The mechanism by which protein 4.2 influences cation transporter activities in RBCs remains a mystery. Na-K$2 \mathrm{Cl}$ cotransporter activity correlates with increasing phosphorylation in shark rectal gland, vascular endothelial cells, intestinal epithelial cells, and duck and ferret RBCs (33-36). In the latter, increased $\mathrm{Na} / \mathrm{H}$ exchanger activity correlates with increased phosphorylation as well. The pattern of cation transporter activities in protein 4.2-deficient mouse RBCs is consistent with an overall increase in RBC phosphorylation, and the basal phosphorylation state of membrane skeleton components in 4.2-deficient RBCs is increased. It will be of interest in future studies to determine if artificially accelerating cation transport pathways (e.g., loading cells with $\mathrm{Na}^{+}$or $\mathrm{Ca}^{2+}$ to accelerate cotransport or the Gardos channel activity, respectively) alters RBC membrane skeleton protein phosphorylation patterns in normal cells. To determine whether any of the changes in kinase activities detected in 4.2-deficient RBCs are causally related to the changes in cation transporter rates in 4.2null RBCs will also require further study.

\section{Acknowledgments}

We thank Alicia Rivera, Totam Nguyen, Michelle Rotter, and Laura Derick for excellent technical assistance; Roderick Bronson for tissue pathology studies; Jennifer L. Smith for computer graphics; and Nancy Wandersee and Connie Birkenmeier for critical review of the manuscript. Supported by National Institutes of Health grants DK-26263 (to N. Mohandas), HL-55321 (to L.L. Peters), DK-34083 (to S.E. Lux), HL-32262 (to S.E. Lux), HL-15157 (to C. Brugnara), HL-32854 (to D.E. Golan), HL15157 (to D.E. Golan), and DK-50422 (to C. Brugnara); a grant from the March of Dimes (to L.L. Peters); and cancer core grant CA-34196 (to The Jackson Laboratory).

1. Korsgren, C., and Cohen, C.M. 1994. cDNA sequence, gene structure, and properties of murine pallidin (band 4.2), the protein implicated in the murine pallid mutation. Genomics. 21:478-485.

2. Lux, S.E., and Palek, J. 1995. Disorders of the red cell membrane. In Blood: principles and practice of hematology. R.I. Handin, S.E. Lux, and T.P. Stossel, editors. J.B. Lippincott. Philadelphia, PA. 1701-1818.

3. Yawata, Y. 1994. Red cell membrane protein band 4.2: phenotypic, genetic and electron microscopic aspects. Biochim. Biophys. Acta. 1204:131-148.

4. Korsgren, C., and Cohen, C.M. 1988. Associations of human erythrocyte protein 4.2. Binding to ankyrin and to the cytoplasmic domain of band 3. J. Biol. Chem. 263:10212-10218.

5. Golan, D.E., et al. 1996. Control of band 3 lateral and rotational mobility by band 4.2 in intact erythrocytes: release of band 3 oligomers from low-affinity binding sites. Biophys. J. 70:1534-1542.

6. Peters, L.L., et al. 1996. Anion exchanger 1 (band 3) is required to prevent erythrocyte membrane surface loss but not to form the membrane skeleton. Cell. 86:917-927.

7. De Franceschi, L., et al. 1997. Membrane cation and anion transport activities in erythrocytes of hereditary spherocytosis: effects of different membrane protein defects. Am. J. Hematol. 55:121-128.

8. Joiner, C., et al. 1995. Increased cation permeability in mutant red blood cells with defective membrane skeletons. Blood. 86:4307-4314.

9. Malik, S., Sami, M., and Watts, A. 1993. A role for band 4.2 in human erythrocyte band 3 mediated anion transport. Biochemistry. 32:10078-10084.

10. Tybulewicz, V.L.J., Crawford, C.E., Jackson, P.K., Bronson, R.T., and Mulligan, R.C. 1991. Neonatal lethality and lymphopenia in mice with a homozygous disruption of the c-abl proto-oncogene. Cell. 65:1153-1163.

11. Hooper, M., Hardy, K., Handyside, A., Hunter, S., and Monk, M. 1987. HPRT-deficient (Lesch-Nyhan) mouse embryos derived from germline colonization by cultured cells. Nature. 326:292-295.

12. Robertson, E.J. 1987. Teratocarcinomas and embryonic stem cells: a practical approach. IRL Press. Oxford, United Kingdom. 254 pp.

13. Chomczynski, P., and Sacchi, N. 1987. Single-step method of RNA isolation by acid guanidinium thiocyanate-phenol-chloroform extraction. Anal. Biochem. 162:156-159.

14. Steck, T.L. 1974. The organization of proteins in the human red cell membrane. J. Cell Biol. 62:1-19.

15. Laemmli, U.K. 1970. Cleavage of structural proteins during the assembly of the head of bacteriophage T4. Nature. 227:680-685

16. Lehnert, M.E., and Lodish, H.F. 1988. Unequal synthesis and differential degradation of $\alpha$ - and $\beta$-spectrin during murine erythroid differentiation. J. Cell Biol. 107:413-426.

17. Savvides, P., Shalev, O., John, K.M., and Lux, S.E. 1993. Combined spectrin and ankyrin deficiency is common in dominant hereditary spherocytosis. Blood. 82:2953-2960.

18. Jöns, T., and Drenckhahn, D. 1992. Identification of the binding interface involved in linkage of the cytoskeletal protein 4.1 to the erythrocyte anion exchanger. EMBO J. 11:2863-2867.

19. Gwynn, B., Korsgren, C., Ciciotte, S., Cohen, C.M., and Peters, L.L. 1997. The gene encoding protein 4.2 is distinct from the mouse platelet storage pool deficiency mutation pallid. Genomics. 42:532-535.

20. Thomas, H.A., Machen, T.E., Smolka, A., Baron, R., and Kopito, R.R. 1989. Identification of a 185-kDa band 3-related polypeptide in oxyntic cells. Am. J. Physiol. 257:C537-C544.

21. Hassoun, H., et al. 1998. Complete deficiency of glycophorin A in red blood cells from mice with targeted inactivation of the band 3 (AE1) gene. Blood. 91:2146-2151.

22. Peters, L.L., and Barker, J.E. 1993. Novel inheritance of the murine severe 
combined anemia and thrombocytopenia (scat) phenotype. Cell. 74:135-142.

23. Swank, R.T., Reddington, M., Howlett, O., and Novak, E.K. 1991. Platelet storage pool deficiency associated with inherited abnormalities of the inner ear in the mouse pigment mutants muted and mocha. Blood. 78:2036-2044.

24. Liu, S.C., et al. 1995. Molecular basis of altered red blood cell membrane properties in Southeast Asian ovalocytosis: role of the mutant band 3 protein in band 3 oligomerization and retention by the membrane skeleton. Blood. 86:349-358.

25. Clark, M.R., Mohandas, N., and Shohet, S.B. 1983. Osmotic gradient ektacytometry: comprehensive characterization of red cell volume and surface maintenance. Blood. 61:899-910.

26. Yi, S.J., et al. 1997. Red cell membranes of ankyrin-deficient $n b / n b$ mice lack band 3 tetramers but contain normal membrane skeletons. Biochemistry. 36:9596-9604.

27. Schofield, A.E., Reardon, D.M., and Tanner, M.J.A. 1992. Defective anion transport activity of the abnormal band 3 in hereditary ovalocytic red blood cells. Nature. 335:836-838.

28. Wolff, D., Cecchi, X., Spalvins, A., and Canessa, M. 1988. Charybdotoxin blocks with high affinity the Ca-activated $\mathrm{K}^{+}$channel of $\mathrm{Hb} \mathrm{A}$ and $\mathrm{Hb}$ $\mathrm{S}$ red cells: individual differences in the number of channels. J. Membr. Biol. 196:243-252.

29. Ai, Z., and Cohen, C.M. 1993. Phorbol 12-myristate 13-acetate-stimulated phosphorylation of erythrocyte membrane skeletal proteins is blocked by calpain inhibitors: possible role of protein kinase. Biochem J. 296:675-683.

30. Danilov, Y.N., Fennell, R., Ling, E., and Cohen, C.M. 1990. Selective modulation of band 4.1 binding to erythrocyte membranes by protein kinase C. J. Biol. Chem. 265:2556-2562.

31. Jindal, H.K., Ai, Z., Gascard, P., Horton, C., and Cohen, C.M. 1996. Specific loss of protein kinase activities in senescent erythrocytes. Blood. 88:1479-1487.

32. Manno, S., Takakuwa, Y., Nagao, K., and Mohandas, N. 1995. Modulation of erythrocyte membrane mechanical function by $\beta$-spectrin phosphorylation and dephosphorylation. J. Biol. Chem. 270:5659-5665.

33. O’Donnell, M.E., Martinez, A., and Sun, D. 1995. Endothelial Na-K-Cl cotransport regulation by tonicity and hormones: phosphorylation of cotransport protein. Am. J. Physiol. 269:C1513-C1523.

34. Klein, J.D., Perry, P.B., and O'Neill, W.C. 1993. Regulation by cell volume of $\mathrm{Na}(+)-\mathrm{K}(+)-2 \mathrm{Cl}$ cotransport in vascular endothelial cells: role of protein phosphorylation. J. Membr. Biol. 132:243-252.

35. Mairbaurl, H., and Herth, C. $1996 . \mathrm{Na}(+)-\mathrm{K}(+)-2 \mathrm{Cl}-$ cotransport, $\mathrm{Na}+/ \mathrm{H}+$ exchange, and cell volume in ferret erythrocytes. Am. J. Physiol. 271:C1603-C1611

36. Lytle, C. 1998. A volume-sensitive protein kinase regulates the $\mathrm{Na}-\mathrm{K}$ $2 \mathrm{Cl}$ cotransporter in duck red blood cells. Am. J. Physiol. 43:C1002-C1010.

37. Hamilton, C.M., and Cohen, C.M. 1996. Non-erythroid forms of human erythrocyte membrane protein 4.2 are found on a unique population of vesicles in platelets and cultured cell lines. Mol. Biol. Cell. 7:434a. (Abstr.) 38. Tanner, M.J.A. 1997. The structure and function of band 3 (AE1): recent developments. Mol. Membr. Biol. 14:155-165.

39. Sheetz, M.P., Schindler, M., and Koppel, D.E. 1980. Lateral mobility of integral membrane proteins is increased in spherocytic erythrocytes. Nature. 285:510-511.

40. Lombardo, C.R., Willardson, B.M., and Low, P.S. 1992. Localization of the protein 4.1-binding site on the cytoplasmic domain of erythrocyte membrane band 3. J. Biol. Chem. 267:9540-9546.

41. Conboy, J.G. 1993. Structure, function, and molecular genetics of erythroid membrane skeletal protein 4.1 in normal and abnormal red blood cells. Semin. Hematol. 30:58-73.

42. Chasis, J.A., and Mohandas, N. 1992. Red blood cell glycophorins. Blood. 80:1869-1879.

43. Discher, D.E., et al. 1995. Mechanochemistry of protein 4.1's spectrinactin-binding domain: ternary complex interactions, membrane binding, network integration, structural strengthening. J. Cell Biol. 130:897-907.

44. An, X.L., Takakuwa, Y., Nunomura, W., Manno, S., and Mohandas, N. 1996. Modulation of band 3-ankyrin interaction by protein 4.1. Functional implications in regulation of erythrocyte membrane mechanical properties. J. Biol. Chem. 271:33187-33191.

45. Shi, Z.-T., et al. 1999. Protein 4.1R-deficient mice are viable but have erythroid membrane skeleton abnormalities. J. Clin. Invest. 103:331-340.

46. Risinger, M.A., Derick, L.H., and Cohen, C.M. 1994. Melanocytes cultured from pallid mice are less melanized than C57 melanocytes and demonstrate differences in pallidin (band 4.2) localization. Mol. Biol. Cell. 5:366a. (Abstr.)

47. White, R.A., et al. 1992. The murine pallid mutation is a platelet storage pool disease associated with the protein 4.2 (pallidin) gene. Nat. Genet. 2:80-83.

48. Erdmann, E., and Hasse, W. 1975. Quantitative aspects of ouabain binding to human erythrocyte and cardiac membranes. J. Physiol. (Lond.) 251:671-682.

49. Joiner, C.H., and Lauf, P.K. 1978. Ouabain binding and potassium transport in young and old populations of human red cells. Membr. Biochem. 1:187-202.

50. Tosteson, D.C., and Hoffman, J.F. 1960. Regulation of cell volume by active cation transport in high and low potassium sheep red cells. J. Gen. Physiol. 44:169-194.

51. Pellegrino, C.M., Rybicki, A.C., Musto, S., Nagel, R.L., and Schwartz, R.S. 1998. Molecular identification and expression of erythroid K:Cl cotransporter in human and mouse erythroleukemic cells. Blood Cells Mol. Dis. 24:31-40.

52. Lima, P.R., Gontijo, J.A., Lopes de Faria, J.B., Costa, F.F., and Saad, S.T. 1997. Band 3 campinas: a novel splicing mutation in the band 3 gene (AE1) associated with hereditary spherocytosis, hyperactivity of $\mathrm{Na}+/ \mathrm{Li}^{+}$ countertransport and an abnormal renal bicarbonate handling. Blood. 90:2810-2818. 